\title{
Hubungan Regulasi Emosi dengan Perilaku Kekerasan dalam Berpacaran pada Mahasiswa
}

\author{
Puspita Megawati ${ }^{1}$, Zainul Anwar ${ }^{2}$, Alifa Nabilah Masturah ${ }^{3}$ \\ Fakultas Psikologi, Universitas Muhammadiyah Malang \\ e-mail: ${ }^{1}$ puspitamg@gmail.com, ${ }^{2}$ zainulanwar@umm.ac.id, ${ }^{3}$ alifah_nabilah@umm.ac.id
}

\begin{abstract}
Ideally dating is sharing mutual love, attention, gentle treatment, intimacy, and romance. However, it is not uncommon to find abusive treatment from their loved ones. Emotional regulation with a poor ability to regulate emotions is associated with emotional arousal which leads to an increase in aggression behavior. The purpose of this study was to determine the relationship of emotional regulation with violent dating behavior in students. This study uses a correlational quantitative research method using a purposive sampling technique. The study was conducted on perpetrators of violence in dating with a total of 183 subjects with an age range of 18-24 years. Data collection uses the scale of DERS adaptation and scale of Violence in Dating. Data analysis method uses Pearson product moment analysis. The results showed a significant correlation between emotional regulation of dating violence $\left(r=0.360 ; r^{2}=0.130 ; p=\right.$ $0,000 ; p<0.05)$.
\end{abstract}

KEYWORDS Dating violence, emotional regulation, students

CITATION Megawati, P., Anwar, Z., \& Masturah, A. N. (2019). Hubungan regulasi emosi dengan perilaku kekerasan dalam berpacaran pada mahasiswa. Cognicia. 7, (2), 214-227.

Pada era milenial saat ini, kata pacaran sudah tidak asing lagi di telinga masyarakat. Khususnya dikalangan mahasiswa dari tingkatan junior sampai tingkatan senior. Mahasiswa berlomba-lomba mencari pasangan yang sesuai dengan hasrat yang mereka miliki. Mulai dari mahasiswa baru masuk, para senior mulai mengincar para juniornya. Tidak jarang dari mereka mencoba untuk menjajahi satu persatu lawan jenis mereka, alasannya hanya untuk mencari pasangan yang dirasa cocok dan bisa diajak ke jenjang yang lebih serius. Idealnya pacaran itu saling berbagi kasih sayang, perhatian, perlakuan lembut, mesra, dan romatis. Namun tidak jarang ditemui perlakuan kasar dari pasangan yang mereka sayangi. Mulai dari perkataan yang kasar sampai perlakuan fisik pun mereka lontarkan terhadap pasangan yang dianggap tidak sesuai dengan keinginannya. Jika perlakuan-perlakuan tersebut terus dilakukan oleh pasangan, hal ini bisa dianggap sebagai tindakan kekerasan dalam berpacaran. Pelaku kekerasan dalam pacaran kebanyakan adalah laki-laki namun tidak menutup kemungkinan yang menjadi pelaku kekerasan adalah perempuan (NET, 2017).

Beberapa bulan lalu, fenomena yang terjadi di Surabaya dengan korban berstatus sebagai mahasiswa aktif mengalami tindak kekerasan oleh pacarnya sendiri yang juga satu kampus dengan korban. Mahasiswa perempuan tersebut dianiaya oleh pacarnya lantaran bertengkar terkait permasalahan yang ada di kampusnya. Berdalih ingin 
menyelesaikan masalah pelaku yang awalnya mengajak korban berboncengan motor dengan alasan jalan-jalan malah membawa pacarnya ke sebuah hotel dan menyiksa korban dengan menampar berkali-kali hingga lemas dan menyeretnya ke kamar mandi kemudian membenamkan kepala korban ke dalam westafel. Setelah melihat pacarnya yang tidak berdaya pelaku akhirnya tega melampiaskan nafsu bejatnya dan memperkosa pacarnya sebanyak 2 kali. Kemudian pelaku memaksa pacarnya untuk tidak melaporkan hal tersebut kepada siapapun. Oleh korban akhirnya, dia menceritkan perlakuan tersebut kepada keluarga akhirnya sampai kerana hukum (Kuniawan, 2018).

Fenomena kekerasan berpacaran berikutnya, yaitu dipicu oleh rasa cemburu yang berakibat fatal bagi pasangannya. Salah satu kasus yang terjadi pada tahun lalu yang dilakukan oleh pasangan mahasiswa yang mengalami kekerasan fisik sehingga menyebabkan perempuan berumur 21 tahun itu mengalami memar di pipi dan dahi. Pelaku membenturkan pacarnya dengan helm saat berboncengan. Awalnya sang pelaku tidak mengakui perlakuannya terhadap korban, dengan alasan tidak sengaja. Setelah diselidiki sering kali korban mendapatkan kekerasan fisik karena terbakar api cemburu yang meilhat kekasihnya berboncengan dengan laki-laki lain (Tarso, 2017).

Selain dari dua kasus tersebut, fenomena lain berasal dari Inggris yang korbannya adalah seorang laki-laki. Laki-laki yang berusia 22 tahun itu bertemu dengan pacarnya atau si pelaku saat mereka berdua masih berusia 16 tahun di kampus pada tahun 2012. Sejak awal hubungan yang memiliki kendali adalah perempuan. Seperti menentukan pakaian apa yang harus dikenakan, dan ketika tidak dituruti oleh korban maka pelaku akan menyerang pacarnya secara fisik. Bentuk perlakuan yang dilami oleh korban seperti mendapat siraman air mendidih, memukul dengan botol bir, memukul dengan palu. Akan tetapi korban kekerasan ini tidak diizinkan oleh pacarnya untuk mendapatkan perawatan medis. Perlakuan kekerasan tersebut akhirnya berakhir saat tetangga korban mendengar teriakan dari rumah, dan segera melaporkan kepada polisi (BBC, 2018).

Menurut Catatan Tahunan (CATAHU) kekerasan dalam pacaran ialah pola perilaku yang tidak menyenangkan (kasar) dan digunakan untuk mengarahkan kekuasaan dan kontrol atas pasangan. Data prevalensi kekerasan dalam pacaran itu sendiri menempati urutan kedua setelah Kekerasan Dalam Rumah Tangga (KDRT) dan relasi personal. Data yang dimiliki Komnas CATAHU tahun 2015 mencatat kasus kekerasan dalam pacaran setiap tahunnya selalu menanjak dan terus bertambah. Pada tahun 2014 tercatat sebanyak 1.784 kasus kekerasan dalam berpacaran dan naik pada tahun 2015 sebanyak 2.734 kasus. Dari data CATAHU urutan kekerasan tertinggi terjadi pada usia 19-24 tahun baik sebagai pelaku (1.335) maupun korban (1.317) (Komnas Perempuan, 2017). Kasus-kasus yang terjadi di era masyarakat khususnya lingkup kampus dengan korban dan pelaku yang menyandang status sebagai mahasiswa mereka tidak ada yang berani melaporkan atas kekerasan yang terjadi.

Mahasiswa berusia 18 tahun - 24 tahun dikategorikan pada masa remaja akhir dan dewasa awal. Pada masa peralihan ini para mahasiswa mendapat dorongan untuk menghadapi berbagai tuntutan dan hal-hal baru. Bentuk-bentuk emosi pada masa remaja akhir menuju peralihan adalah: Marah, emosi yang tidak stabil, cara berfikirnya berdasarkan sebab dan akibat, takut dan cemas, jealousy, dan envy. Konteks pacaran 
pada remaja memiliki dampak positif dan negatif. Dampak negatif dalam berpacaran pada masa ini yaitu adanya dampak psikologis dan dampak seksual. Dampak psikologis yaitu Perempuan menjadi trauma atau benci kepada laki-laki, dampak seksual yaitu mengalami sebuah traumatik bagi para korban dan orang-orang yang dekat dengan korban (Safitri, 2013).

Berdasarkan hasil pengamatan dari beberapa mahasiswa yang pernah mengalami kekerasan dalam berpacaran sekitar bulan oktober lalu. Tindakan kekerasan yang dilakukan oleh pasangannya biasanya berupa kekerasan fisik seperti menampar, memukul, menggigit, mencakar serta bersikap kasar yang bersifat melukai perasaan korban. Pelaku juga tidak segan untuk berselingkuh di depan korban. Pada korban lain mendapat kekerasan berpacaran dengan dipaksa untuk melakukan hubungan seks dengan pasangannya, dengan ancaman jika tidak ingin melakukan akan putus hubungan. Pada korban lain oleh pasangannya dipaksa untuk mengirimkan foto-foto telanjang korban dan berhubungan seksual dengannya, yang dibuat pelaku untuk mengancam para korban. Pelaku memberi ancaman bahwa tidak akan bertanggung jawab dengan hasil hubungan badannya.

Kekerasan dalam berpacaran merupakan suatu perlakuan berupa kekerasan fisik atau seksual dalam konteks hubungan berpacaran yang dianggap sebagai masalah yang kerap ada di masayarakat yang cukup serius dan penting. Pengertian dari kekerasan dalam berpacaran itu sendiri berarti suatu perilaku yang melibatkan terjadinya kekerasan fisik, psikologis, dan kekerasan seksual pada pacar. Bentuk dari kekerasan yang dialami oleh para mahasiswa dikelompokkan sebagai tiga. Pertama yang termasuk dalam kekerasan psikis adalah menghina, meneriaki, menyumpahi. Kedua kekerasan fisik yaitu mendorong, atau menampar pasangan. Ketiga kekerasan seksual yaitu memaksa melakukan seks dengan pasangan yang tidak ingin melakukan hubungan seks (Shorey, Cornelius, \& Bell, 2008).

Pada kekerasan dalam pacaran tidak akan separah KDRT khususnya yang berkaitan dengan kekerasan fisik (Shorey et al., 2008). Hal ini disebabkan karena para mahasiswa yang sering memiliki hubungan (status pacaran) memiliki durasi pendek (Cooper, 2002). Kekerasan dalam berpacaran sangat menarik untuk dibahas. Karena fenomena tersebut dari waktu-kewaktu jumlahnya terus meningkan. Dari hasil prevalensi atau data yang tercatat hanya sebagian besar yang dilaporkan. Tidak ada catatan khusus tentang seseorang yang melakukan perilaku kekerasan saat berpacaran. Di Indonesia sendiri bahkan tidak ada catatan khusus bahwa ada korban laki-laki dan pelakunya adalah seorang wanita. Hal tersebut yang membuat penelitian ini sangat menarik jika ditinjau dari segi regulasi emosi yang dimiliki oleh seseorang yang berpacaran. Karena regulasi emosi dibawah sejak lahir tegantung individu bagaimana ia mengelolahnya agar tidak diubah kebentuk perilaku agresi atau yang biasa disebut dengan perilakuu kekerasan.

Regulasi emosi berarti sebagai suatu kemampuan yang dimiliki oleh individu untuk menilai, mengatasi, mengelola, dan mengungkapkan emosi yang tepat untuk mencapai keseimbangan emosional. Emosional yang kurang tepat dapat menimbulkan permasalahan yang justru dapat merugikan diri sendiri maupun orang lain. Oleh karena itu diperlukan suatu strategi yang dapat diterapkan untuk menghadapi situasi emosional yang berupa regulasi emosi dan dapat mengurangi pengalaman- 
pengalaman emosi negatif maupun tingkah laku maladaptif (Gross, 2014). Regulasi emosi juga dapat memepengaruhi perilaku dan pengalaman seseorang. Hasil dari regulasi biasanya berupa perilaku yang tidak diinginkan, dikurangi, atau dihambat oleh ekspresi. Selain itu, regulasi emosi juga berpengaruh terhadap pembentukan kepribadian individu dan menjadi sumber penting bagi perbedaan tiap individu.

Pada penelitian sebelumnya yang membahas mengenai prevalensi dan juga korelasi dari kekerasan dalam berpacaran oleh (Wolitzky-taylor \& Ruggiero, 2008) yaitu diperoleh hasil 1,6\% (2,7\% anak perempuan dan 0,6\% anak laki-laki) sekitar 400.000 remaja yang populasinya berasal dari AS. Dipaparkan bahwa faktor terjadinya kekerasan dalam berpacaran adalah faktor stressor kehidupan, yang menyatakan bahwa kekerasan dalam berpacaran terkait dengan gangguan stress pasca trauma dan peristiwa yang menegangkan. Penelitian tersebut berfokus pada pencegahan. Dimana para remaja untuk belajar memanajemen kemarahan dan keterampilan koping lainnya, serta dihimbau untuk memberitahu dampak negatif penggunaan perilaku kekerasan dalam berpacaran. Hal tersebut mungkin adalah cara efektif untuk mengurangi kekerasan dalam berpacaran.

Penelitian lain yang dilakukan oleh (Shorey, McNulty, Moore, \& Stuart, 2015) yang membahas mengenai pengaruh negatif proksimal yang dapat meningkatkan perilaku agresi, diperoleh hasil dari penelitian tersebut menunjukkan bahwa regulasi emosi memoderasi banyak asosisasi seperti pengaruh negatif proksimal dan agresi fisik, sehingga hal tersebut dikaitkan dengan peningkatan kemungkinan kekerasan ketika regulasi emosi yang buruk tinggi tetapi tidak rendah.

Pada penelitian lain oleh (Shorey, Brasfield, Febres, \& Stuart, 2011) mengenai kemampuan regulasi emosi terhadap kekerasan dalam berpacaran dengan subjek sebanyak 440 mahasiswa. Temuan menunjukkan bahwa hubungan antara kesulitan regulasi emosi serta masalah regulasi emosi yang lebih spesifik, dikaitkan dengan penanggalan kekerasan dan dapat membedakan individu yang telah melakukan dan atau tidak melakuakan agresi. Temuan tersebut sedikit bervariasi tergantung jenis kelamin pelaku dan jenis agresi yang diperiksa. Laki-laki dan perempuan memiliki agresi seksual dilakukan dengan motivasi yang berbeda. Ketika berada dalam emosi negatif, kondisi khusus seperti perilaku agresi yang nampak lebih mungkin terjadi pada laki-laki. Hal ini karena laki-laki yang ada di perguraun tinggi memiliki gairah seksual yang tinggi terhadap rangsangan agresif. Laki-laki cenderung menggunkan kekerasan untuk memunculkan hasrat seksual karena lebih mendapatkan perhatian. Ketika emosi negatif muncul diubah menjadi kekerasan gairah seksual.

Penelitian yang dilakukan oleh (Shorey et al., 2012) mengenai hubungan antara alkohol dan obat-obatan dengan kekerasan dalam berpacaran memeperoleh hasil bahwa penggunaan alkohol sangat konsisten terkait dengan tindakan kekerasan untuk pria dan wanita yang sedang kuliah. Dijelaskan bahwa laki-laki yang meminum minuman keras dan juga pesta minuman keras lebih mungkin melakukan agresi fisik dan seksual daripada laki-laki tanpa permasalahan seperti itu. Begitu juga dengan wanita yang bermasalah dengan minuman keras juga berpotensi lebih besar cenderung menjadi pelaku agresi fisik. Untuk narkorba tidak semua memiliki kemungkinan memicu seseorang untuk melakukan agresi fisik. Ganja adalah salah satu obat yang telat terbukti memiliki potensi untuk individu melakukan kekerasan 
fisik. Hasil penelitian menunjukkan bahwa laki-laki korban agresi fisik mungkin lebih cenderung merokok sedangkan perempuan lebih cenderung menggunkan zat-zat ilegal.

Berdasarkan dari fenomena yang ada dan juga hasil penelitian sebelumnya mengenai kekerasan dalam berpacaran, setiap individu memiliki potensi untuk melakukan perilaku kekerasan saat berpacaran. Oleh sebab itu peneliti ingin meneliti mengenai "Hubungan regulasi emosi dengan perilaku kekerasan dalam berpacaran pada mahasiswa". Penelitian ini penting untuk dilaksanakan karena belum ada penelitian di Indonesia yang membahas mengenai kedua variabel secara bersamaan. Dengan adanya penelitian ini akan memberikan dampak pada penelitian selanjutnya. Selain itu dengan adanya penelitian tersebut diharapkan akan ada pengurangan tingkatan individu yang memiliki potensi perilaku kekerasan dalam berpacaran.

Tujuan dari penelitian ini yaitu untuk hubungan regulasi emosi dengan perilaku kekerasan dalam berpacaran pada mahasiswa. Selain itu penelitian ini bertujuan untuk melihat potensi dari perilaku kekerasan ditinjau dari regulasi emosi masing-masing individu yang berpacaran sesuai dengan gender. Manfaat untuk penelitian ini yaitu untuk mengetahui gambaran dari hubungan regulasi emosi dengan perilaku kekerasan dalam berpacaran pada mahasiswa. Serta membantu melengkapi hasil penelitian sebelumnya yang membahas tentang variabel tersebut. Penelitian ini juga dapat membantu memberikan acuan himbauan pada mahasiswa untuk meregulasi emosi sehingga tidak melakukan perilaku kekerasan dalam berpacaran untuk menyelesaikan masalah dalam hubungan mereka. Hipotesa dalam penelitian ini adalah terdapat hubungan antara regulasi emosi dengan kekerasan dalam berpacaran pada mahasiswa.

\section{METODE}

Rancangan penelitian ini menggunakan pendekatan kuantitatif. Dimana data yang didapat berupa angka-angka dan diolah dengan menggunakan teknik statistik. Dengan desain penelitian korelasional untuk mengetahui hubungan antara variabel satu dengan varibel lain. penelitian korelasional mempermudah memahami dari suatu fenomena yang diteliti. Serta menggunakan jenis penelitian asosiatif, yang memiliki fungsi untuk menjelaskan, meramalkan serta mengontrol dari suatu gejala fenomena yang ada (Sugiyono, 2018).

Pengambilan sampel dalam penelitian ini menggunakan karakteristik subjek yakni merupakan mahasiswa aktif yang berusia 18-24 tahun sebanyak 183 orang. Berjenis kelamin laki-laki sebanyak 70 orang dan perempuan sebanyak 113 yang sedang menjalin hubungan berpacaran dan sekaligus memiliki kecenderungan untuk melakukan kekerasan dalam berpacaran (pelaku kekerasan dalam berpacaran). Teknik penarikan sampel dalam penelitian ini yaitu nonprobabilitas yang mana merupakan suatu teknik penarikan sampel yang mendasarkan pada setiap anggota populasi tidak memiliki kesempatan yang sama, sehingga dengan menggunakan teknik ini dapat digunakan untuk memprediksi populasi. Adapun jenis teknik sampel yang digunakan adalah teknik purposive sampling dengan cara menentukan kriteria khusus terhadap sampel, terutama orang-orang yang dianggap ahli (Priyono, 2016). 
Penelitian ini terdiri dari dua variabel, yaitu variabel bebas $(X)$ dan variabel terikat $(\mathrm{Y})$. Variabel bebas (X) (independent variabel) dalam penelitian ini yaitu Regulasi Emosi. Sedangkan variabel terikat (Y) (dependent variabel) adalah kekerasan dalam berpacaran. Yang dimaksud dengan regulasi emosi dalam penelitian merupakan individu yang memiliki kemampuan untuk mengatasi masalah atau memiliki strategi dengan cara mengurangi emosi negatif dengan menekan diri kembali setelah merasakan emosi, memiliki tujuan untuk tetap berpikir dan berperilaku baik setelah terpengaruh emosi negatif, memiliki kontrol untuk mendorong emosi negatif sehingga menampilkan respon emosi yang tepat, serta memiliki kemampuan untuk menerima suatu peristiwa yang menimbulkan emosi negatif tanpa merasa malu untuk merasakan emosi yang dirasakan tersebut. Sedangkan yang dimaksud dengan kekerasan dalam berpacaran yaitu individu yang mengacu pada tindakan agresi yang mengakibatkan pasangan terluka secara fisik, melakukan ancaman yang dilakukan dengan perkataan maupun mimik wajah terhadap pasangannya, serta berupa paksaan untuk melakukan kontak seksual dengan pasangannya.

Instrumen dalam penelitian ini menggunakan adaptasi skala dari Difficulties in Emotion Regulation Scale (DERS) yang dikembangkan oleh Kim L. Gratz dan Elizabeth Roemer. DERS memiliki enam faktor penilian yaitu berupa Nonacceptenceof Emotional Responses (NONACCEPTANCE), Difficulties Engaging in Goal-Directed Behavior (GOALS), Impulse Control Difficulties (IMPULSE), Lack of Emotional Awareness (AWARENESS), Limited Access to Emotional Regulation Strategies (STRATEGIES), dan Lack of Emotional Clarity (CLARITY) yang terdiri dari 36 item yang dikembangkan dari empat dimensi regulasi emosi (Gratz \& Roemer, 2004). Sedangkan instrumen kedua yaitu dengan menggunakan skala kekerasan dalam berpacaran yang dikembangkan oleh peneliti sesuai dengan aspek agresi fisik, agresi verbal dan emosional, dan agresi seksual milik Murray dengan total item sebanyak 68 butir.

Kedua alat ukur yang digunakan dalam penelitian ini yaitu menggunakan skala likert untuk menentukan sikap dengan item pendukung konsep (favorable) dan item yang tidak mendukung (unfavorable) untuk menilai skala DERS. Dengan 5 alternatif pilihan jawaban berupa Sangat Tidak Setuju (STS), Tidak Setuju (TS), Netral (N), Setuju (S), Sangat Setuju (SS). Rincian penilian favorable berupa item Sangat Setuju (SS) diberikan nilai 5, Setuju (S) diberikan nilai 4, Netral (N) diberikan nilai 3, Tidak Setuju (TS) diberikan nilai 2, Sangat Tidak Setuju (STS) diberikan nilai 1. Begitupun sebaliknya untuk penilaian unfavorable Sangat Setuju (SS) diberikan nilai 1, Setuju (S) diberikan nilai 2, Netral (N) diberikan nilai 3, Tidak Setuju (TS) diberikan nilai 4, Sangat Tidak Setuju (STS) diberikan nilai 5.

Tabel 1. Indeks Validitas dan Reliabilitas Alat Ukur Penelitian

\begin{tabular}{ccccc}
\hline Alat Ukur & $\begin{array}{c}\text { Jumlah Item } \\
\text { Diujikan }\end{array}$ & $\begin{array}{c}\text { Jumlah Item } \\
\text { Valid }\end{array}$ & $\begin{array}{c}\text { Indeks } \\
\text { Validitas }\end{array}$ & $\begin{array}{c}\text { Indeks } \\
\text { Reliabilitas }\end{array}$ \\
\hline $\begin{array}{c}\text { Regulasi Emosi } \\
\text { Kekerasan dalam } \\
\text { Berpacaran }\end{array}$ & 36 item & 28 item & $0,324-0,787$ & 0,903 \\
& 68 item & 43 item & $0,307-0,806$ & 0,935 \\
\hline
\end{tabular}


Prosedur pertama yang dilakukan oleh peneliti yaitu menyusun instrumen penelitian. Untuk instrumen regulasi emosi menggunakan skala adapatasi DERS milik Kim L. Gratz dan Elizabeth Roemer. Sedangkan untuk instrumen penelitian kekerasan dalam berpacaran, peneliti menyusun sendiri berdasarkan aspek dan indikator kekerasan dalam berpacaran milik Jill Murray. Kemudian peneliti mengkonsultasikan kedua skala kepada dosen pembimbing sehingga dapat dilakukan try out untuk memperoleh hasil validitas dan reliabilitas pada kedua instrumen. Uji coba skala atau tryout dimulai dari tanggal 2 - 21 Februari 2019. Setelah diperoleh data validitas dan reliabilitas, kemudian butir item yang signifikan dapat dijadikan skala untuk mengukur kedua variabel.

Pengambilan data dilakukan pada subjek yang memiliki karateristik khusus yaitu mahasiswa berumur 18-24 tahun yang sedang menjalin hubungan berpacaran dan serta menjadi pelaku kekerasan dalam berpacaran. Pada tahap pelaksanakan dilakukan pada tanggal 14-21 Maret 2019. Peneliti melaukan penyebaran skala melalui media sosial yang mana diperoleh responden sebanyak 832 dengan status pernah terlibat kekerasan dalam berpacaran baik sebagai pelaku maupun korban. Kemudian dilakukan metode screening untuk membedakan antara pelaku kekerasan dan korban kekerasan dalam berpacaran, sehingga hasil akhir diperoleh sebanyak 183 subjek yang sesuai dengan kriteria responden. Teknik pengambilan data menggunakan purposive sampling, dimana responden yang dipilih yang sesuai dengan karakteristik khusus yang telah ditentukan.

Kemudian tahap tiga, yaitu tahap analisa dimana dari hasil perolehan data akan diskoring sesuai dengan butir favorable dan unvaforable dengan memasukkan ke dalam Microsoft Excel. Pada tahap selanjutnya data yang telah diskoring kedalam Microsoft Excel akan dianalisis dengan menggunakan Statical Product and Service Solution (SPSS) 22. Setelah itu dianalisa dengan menggunakan uji asumsi, uji korelasi bivariate pearson dengan analisis product moment pearson dan uji beda.

\section{HASIL}

Penelitian ini menguraikan mengenai hubungan regulasi emosi dengan perilaku kekerasan dalam berpacaran pada mahasiswa. Penelitian ini bertujuan untuk mengetahui seberapa besar hubungan regulasi emosi secara signifikan dengan perilaku kekereasan dalam berpacaran. Dalam penelitian ini, diambil sebanyak 183 subjek sebagai sampel penelitian. Adapun deskripsi hasil penelitian sebagai berikut:

Tabel 2. Deskripsi Data

\begin{tabular}{ccccccc}
\hline Variabel & Kategori & Interval & Frekuensi & Persentase & Mean & SD \\
\hline Regulasi & Rendah & $37-86$ & 84 & $45,9 \%$ & 85,77 & 19,791 \\
Emosi & Tinggi & $87-134$ & 99 & $54,1 \%$ & & \\
& & & & & & \\
Kekerasan & Rendah & $67-93$ & 100 & $54,6 \%$ & 93,53 & 151,107 \\
dalam & Tinggi & $94-131$ & 83 & $45,4 \%$ & & \\
Berpacaran & & & & & & \\
\hline
\end{tabular}


Berdasarkan tabel 2 menunjukkan data kategori variabel regulasi emosi dengan nilai mean sebesar 85,77 dan standart deviasi sebesar 19,791. Pada variabel regulasi emosi kategori tertinggi sebanyak 54,1\% yaitu 99 subjek. Pada ketegori rendah sebanyak $45,9 \%$ yaitu sebanyak 84 subjek. Data kategori variabel kekerasan dalam berpacaran dengan nilai mean sebesar 93,53 dan nilai standart deviasi sebesar 15,107. Variabel kekerasan dalam berpacaran kategori tinggi sebanyak 45,4\% yaitu sebanyak 83 subjek, sedangkan pada kategori rendah sebanyak 54,6\% yaitu sebanyak 100 subjek.

Tabel 3. Uji Beda

\begin{tabular}{|c|c|c|c|c|c|c|c|}
\hline \multirow{2}{*}{ Variabel } & \multicolumn{2}{|c|}{ Mean } & \multicolumn{5}{|c|}{ Equal Variances Assumed } \\
\hline & Laki-laki & Perempuan & $\mathbf{F}$ & Sig. & $\mathbf{t}$ & df & Sig. (2-tailed) \\
\hline \multicolumn{8}{|l|}{ Regulasi } \\
\hline Emosi & 83,19 & 87,36 & 1,706 & 0,193 & 1,391 & 181 & 0,166 \\
\hline $\begin{array}{c}\text { Kekerasan } \\
\text { dalam }\end{array}$ & 93,59 & 93,50 & 4,488 & 0,035 & 0,039 & 181 & 0,969 \\
\hline Berpacaran & & & & & & & \\
\hline
\end{tabular}

Berdasarkan tabel 3 diperoleh hasil nilai dari mean variabel regulasi emosi pada jenis kelamin laki-laki sebesar 83,19 dan perempuan sebesar 87,35. Dengan demikian secara deskriptif statistik dapat disimpulkan bahwa ada perbedaan rata-rata hasil regulasi emosi pada subjek laki-laki dan perempuan. Sedangkan pada variabel kekerasan dalam berpacaran antara jenis kelamin laki-laki sebesar 93,59 dan perempuan sebesar 93,50, sehingga dapat diketahui bahwa pada variabel kekerasan dalam berpacaran secara deskriptif statistik ada sedikit perbedaan rata-rata nilai kekerasan dalam berpacaran.

Berdasarkan nilai Sig. (2-tailed) pada variabel regulasi emosi sebesar 0,166 >0,05, maka pengambilan keputusan uji independet sample $t$ test dapat disimpulkan bahwa tidak ada perbedaan yang signifikan (nyata) pada masing-masing gender. Pada nilai Sig. (2-tailed) pada variabel kekerasan dalam berpacaran sebesar 0,969>0,05, maka pengambilan keputusan uji independet sample $t$ test dapat disimpulkan bahwa tidak ada perbedaan yang signifikan (nyata).

Pengambilan keputusan berdasarkan perbandingan nilai $t$-hitung dengan $t$-tabel dalam uji independent sample $t$ test dengan nilai $d f 181$ sehingga diperoleh hasil untuk $t$ tabel sebesar 1,973 dengan acuan rumus $(\alpha / 2)$; $(d f)$ sama dengan $(0,05 / 2)$; (181). Sehingga diketahui bahwa t-hitung pada regulasi emosi 1,391 $<1,973$ yang berarti tidak ada perbedaan antara pengaruh dari masing-masing gender. Pada $t$ hitung kekerasan dalam berpacaran 0,039 < 1,973 yang berarti tidak ada perbedaan pengaruh gender.

Berdasarkan uji normalitas dengan menggunakan Kolmogrov-Smirnov diketahui bahwa nilai signifikansi (2-tailed) pada regulasi emosi sebesar 0,067 dan kekerasan dalam berpacaran sebesar 0,058 kedua variabel menunjukkan lebih besar dari taraf signifikan $(0,05)$, maka dapat diasumsikan bahwa variabel regulasi emosi $(X)$ dan kekerasan berpacaran $(\mathrm{Y})$ tersebut telah memperlihatkan data berdistribusi normal. 
Berdasarkan uji linearitas yang telah dilakukan diperoleh asumsi bahwa kedua variabel dikatakan memiliki hubungan yang linier apabila nilai sinifikansi < 0,05. Sehingga terhadapat hubungan linier yang signifikan antara variabel independen dengan variabel dependen, begitu pula sebaliknya. Hasil uji linearitas diperoleh hasil signifikansi sebesar 0,000 atau kurang dari 0,05 artinya bahwa variabel regulasi emosi memiliki hubungan yang linier secara signifikan dengan variabel kekerasan dalam berpacaran. Asumsi lain yaitu kedua variabel dikatakan memiliki hubungan yang linier apabila nilai sig. deviation from linierity $>0,05$, berdasarkan dari hasil uji linearitas diketahui bahwa nilai sig. deviation from linierity sebesar 0,712 atau lebih dari 0,05 sehingga dapat diartikan kedua variabel memiliki hubungan yang linier antara satu sama lain.

Tabel 4. Uji Hipotesa

\begin{tabular}{cccc}
\hline $\begin{array}{c}\text { Koefisien Korelasi } \\
(\mathbf{r})\end{array}$ & $\begin{array}{c}\text { Koefisien } \\
\text { Determinasi }\left(\mathbf{r}^{2}\right)\end{array}$ & Beta $(\boldsymbol{\beta})$ & $\begin{array}{c}\text { Nilai Signifikansi } \\
(\mathbf{p})\end{array}$ \\
\hline 0,360 & 0,130 & 0,360 & 0,000 \\
\hline
\end{tabular}

Berdasarkan tabel 4 pada uji hipotesa diketahui dari analisa product moment pearson ditemukan bahwa hipotesa penelitian diterima yang artinya regulasi emosi berhubungan signifikan terhadap kekerasan dalam berpacaran $(r=0,360 ; p=0,000 ; p<$ 0,05). Hasil bernilai positif sehingga dapat disimpulkan bahwa terdapat hubungan yang searah antara regulasi emosi terhadap kekerasan dalam berpacaran yang artinya semakin tinggi regulasi emosi maka semakin tinggi kekerasan dalam berpacaran, begitu pula sebaliknya. Besar kontribusi hubungan regulasi emosi terhadap kekerasan berpacaran sebesar $13 \%$ dan sisanya $87 \%$ ditentukan oleh variabel lainnya.

\section{DISKUSI}

Berdasarkan hasil penelitian ini diketahui bahwa ada hubungan yang signifikan antara regulasi emosi dengan perilaku kekerasan dalam berpacaran. Hal ini dibuktikan dengan adanya nilai t sebesar 0,000 yang menunjukkan kurang dari taraf signifikansi yaitu 0,05 yang berarti berpengaruh sangat kuat. Pada uji hipotesa diketahui dari analisa product moment pearson ditemukan bahwa hipotesa penelitian diterima yang artinya regulasi emosi hubungan signifikan dengan kekerasan dalam berpacaran. Hasil bernilai positif sehingga dapat disimpulkan bahwa terdapat hubungan yang searah antara regulasi emosi dengan kekerasan dalam berpacaran yang artinya semakin tinggi regulasi emosi maka semakin tinggi kekerasan dalam berpacaran, begitu pula sebaliknya. Pada penelitian lain yang membahas mengenai regulasi emosi berpendapat bahwa regulasi emosi yang efektif perlu diperoleh bagi setiap individu. Emosi adalah proses melibatkan respon seluruh tubuh terhadap kejadian-kejadian penting, biasanya mengacu pada stress dan tanggapan sikap negatif lainnya. Sedangkan emosi mengacu kepada dua sikap negatif atau positif (Baird, 2015).

Individu yang menunjukkan regulasi emosi yang buruk dapat mengalami tingkat gairah yang emosional beresiko lebih besar untuk melakukan suatu tindak kekerasan. Penelitian terhadap pria yang berpacaran dan pria yang telah menikah 
menyimpulkan bahwa mereka yang memiliki riwayat melakukan kekerasan terhadap pasangan menyatakan lebih banyak niat melakukan suatu perilaku agresi atau kekerasan selama dalam keadaan marah daripada pria tanpa riwayat yang melakukan kekerasan (Luthra \& Gidycz, 2006).

Penelitian ini mendukung penelitian yang menyatakan riwayat kekerasan dalam berpacaran terlibat lebih banyak perilaku kemarahan dalam bentuk ekspresif yang sering terjadi, sekaligus menunjukkan kontrol yang kurang terhadap kemarahan mereka. Mereka memiliki keterampilan mengontrol emosi yang lebih buruk daripada individu yang tidak memiliki riwayat kekerasan dalam berpacaran. Oleh karena itu, kemampuan buruk dalam meregulasi emosi dikaitkan dengan gairah emosional yang berujung pada peningkatan perilaku agresi (Luthra \& Gidycz, 2006).

Besar kontribusi hubungan regulasi emosi terhadap kekerasan berpacaran sebesar $13 \%$ dan sisanya $87 \%$ ditentukan oleh variabel lain. Kekerasan dalam berpacaran dapat dipengaruhi oleh variabel lain berdasarkan faktor-faktor yang dipaparkan oleh Riggs dan O Leardry (1989). Beberapa variabel yang dapat diteliti pada penelitian selanjutnya seperti kepribadian, stress, dan kepuasan hubungan. Menurut Florence Littauer dalam bukunya yang berjudul Personality Plus, membahas kepribadian adalah seluruh perilaku seseorang individu dengan sistem kecenderungan tertentu yang berinteraksi dengan serangkaian situasi (Littaurer, 2006). Maka dari situasi tersebut individu akan mempelajari suatu kejadian yang membuat individu membentuk perilaku seperti kekerasan dalam penyelesaian masalahnya dan atau mungkin dengan alasan lainnya. Stres dalam menjalani hubungan dengan seseorang bisa menjadi sangat lumrah untuk dipahami. Pada usia remaja akhir menuju dewasa awal disinggung bahwa pada masa itu mengalami berbagi tuntutan. Teori ketegangan Merton (1938) menjelaskan bahwa kekerasan adalah bentuk inovasi dimana seseorang menggunakan kekuatan dalam upaya untuk mencapai sebuah pemenuhan tujuan dari sebuah tekanan. Akibat tekanan stres untuk memenuhi sebuah harapan, hal ini menyebabkan banyak ketegangan. Dan beberapa diantaranya ditemukan ketegangan dalam hubungan menjadi sebab dan akibat seseorang melakukan kekerasan dalam berpacaran. Kepuasan dalam hubungan dapat dipenuhi ketika pasangan intim saling berusaha untuk memahami, memenuhi, dan menegosiasikan harapan yang berpotensi tidak realistis dari keiintiman dan ketergantungan (Mason \& Smithey, 2012).

Responden dalam penelitian ini adalah mahasiswa yang berusia dari 18 tahun 24 tahun. Dimana pada usia ini, mahasiswa pada kategori remaja akhir dan dewasa awal. Masa peralihan yang dialami oleh mahasiswa, mendorong mahasiswa untuk menghadapi berbagai tuntutan dan hal-hal baru. Bentuk-bentuk emosi pada masa remaja akhir adalah: Marah, Emosi yang tidak stabil, cara berfikirnya berdasarkan sebab dan akibat, takut dan cemas, Jealousy, Envy. Konteks pacaran pada remaja memiliki dampak positif dan negatif. Dampak positif dari berpacaran, meliputi sebagai masa rekreasi: sumber status dan prestasi, proses sosialisasi, kemampuan untuk bergaul secara intim, akrab, terbuka, dan bersedia untuk melayani atau membantu individu lawan jenis, penyesuaian normatif, masa sharing: mengekspresikan perasaan, pemikiran, atau pengalaman, dan sebagai masa pengembangan identitas. Dampak negatif dijelaskan Santrok (2007) adanya dampak psikologis dan dampak seksual. Dampak psikologis yaitu Perempuan menjadi trauma atau benci kepada laki-laki, 
dampak seksual yaitu mengalami sebuah traumatik bagi para korban dan orang-orang yang dekat dengan korban (Safitri, 2013).

Responden terbanyak dalam penelitian ini yaitu perempuan sebanyak 113 subjek atau sebesar $61,75 \%$. Sedangkan responden dengan jenis kelamin laki-laki sebanyak 70 subjek atau sebesar 38,25\%. Penelitian ini sekaligus menguatkan penelitian sebelumnya yang mengevaluasi teori model Riggs dan O'Leary (1989) tentang kekerasan dalam berpacaran. Yang mana 25\% wanita dan 10\% wanita melaporkan dirinya sendiri tentang insiden kekerasan dalam berpacaran yang mereka lakukan. Hasil dari penelitian sebelumnya mengklarifikasi 83\% kekerasan dilakukan oleh wanita dan hanya $30 \%$ oleh pria (Luthra \& Gidycz, 2006). Berdasarkan uji beda nilai dari mean variabel regulasi emosi pada jenis kelamin laki-laki sebesar 83,19 dan perempuan sebesar 87,35. Dengan demikian secara deskriptif statistik dapat disimpulkan bahwa ada perbedaan rata-rata hasil regulasi emosi pada subjek laki-laki dan perempuan. Sedangkan pada variabel kekerasan dalam berpacaran antara jenis kelamin laki-laki sebesar 93,59 dan perempuan sebesar 93,50, dapat diketahui bahwa pada variabel kekerasan dalam berpacaran secara deskriptif statistik ada sedikit perbedaan rata-rata nilai kekerasan dalam berpacaran.

Berdasarkan nilai Sig. (2-tailed) pada variabel regulasi emosi sebesar 0,166 >0,05, maka pengambilan keputusan uji independet sample t test dapat disimpulkan bahwa tidak ada perbedaan yang signifikan (nyata) pada masing-masing gender. Pada nilai Sig. (2-tailed) pada variabel kekerasan dalam berpacaran sebesar 0,969>0,05, maka pengambilan keputusan uji independet sample $t$ test dapat disimpulkan bahwa tidak ada perbedaan yang signifikan (nyata). Ada beberapa penjelasan potensial, seperti alasan dan kegagalan untuk melaporkan agresi. Laki-laki yang memukul perempuan dianggap kurang diterima dibanding perempuan yang melakukan kekerasan terhadap laki-laki. Penjelasan kedua yang masuk akal adalah laki-laki mungkin tidak melaporkan secara akurat atau mereka mampu meminimalkan agresi mereka. Menurut Arias dan Johnson (1989) penting untuk dicatat juga bahwa tindakan kekerasan yang dilakukan oleh laki-laki umumnya lebih merusak dan mengakibatkan cedera yang lebih besar pada korban. Selain itu perilaku kekerasan sering diabaikan atau dianggap kurang signifikan hanya karena kedua orang tersebut saling terlibat hubungan yang dekat (Lewis \& Fremouw, 2001).

Penggunaan kekerasan oleh wanita jauh lebih reaktif daripada penggunaan kekeraasan oleh pria. Artinya perempuan dengan pasangan yang melakukan kekerasan lebih mungkin untuk membalas perlakuan pasangannya "melawan api dengan api", dengan menimbulkan kekerasan sebagai respon terhadap kekerasan dalam berpacaran. Penggunaan alkohol adalah prediktor terbesar berikutnya pada tindak kekerasan yang dilakukan wanita. Wanita yang melaporkan penggunaan alkohol lima kali lebih mungkin melakukan kekerasan terhadap pasangan kencan mereka, demikian pula dengan pria (Luthra \& Gidycz, 2006).

Secara khusus, wanita dengan ayah yang kasar hampir tiga kali lebih mungkin melakukan kekerasan terhadap pasangan kencan mereka. Hal ini tidak berlaku untuk pelaku laki-laki, bahwa penerimaan kekerasan orangtua mungkin memiliki dampak yang lebih besar bagi perempuan dibandingkan dengan laki-laki. Durasi hubungan adalah salah satu faktor terjadinya kekerasan pada pelaku laki-laki. Setiap peningkatan 
6 bulan dalam durasi pacaran, maka laki-laki menjadi dua kali lebih mungkin untuk melakukan kekerasan. Penelitian sebelumnya juga menunjukkan bahwa seiring meningkatnya lama durasi hubungan, keparahan pelecehan semakin meningkat (Luthra \& Gidycz, 2006).

Dengan demikian, individu membutuhkan sistem regulasi emosi yang baik ketika dihadapkan dengan emosi yang cukup sulit akan mampu untuk mengendalikan dan dapat terus terlibat dalam perilaku yang dapat diarahkan sesuai dengan tujuan. Regulasi emosi yang baik membutuhkan keterampilan yang mendasari seperti kesadaran dan penerimaan secara emosional. Begitupun sebaliknya, seseorang yang memiliki regulasi emosi yang buruk tidak akan mamapu mengendalikan emosi yang sulit dan tidak dapat mengarahkan pada tujuan yang diinginkan. Kemampuan buruk untuk mengatur emosi dikaitkan dengan peningkatan agresi (Roberton, Daffern, \& Bucks, 2012). Berdasarkan hasil penelitian diperoleh data kategori variabel regulasi emosi dengan nilai mean sebesar 85,77 dan standart deviasi sebesar 19,791. Pada variabel regulasi emosi kategori tertinggi sebanyak 54,1\% yaitu 99 subjek. Pada ketegori rendah sebanyak $45,9 \%$ yaitu sebanyak 84 subjek. Dengan demikian berdasarkan data tersebut dapat diketahui bahwa responden mahasiswa memiliki regulasi emosi dengan interval sedang sampai kategori tinggi.

Sedangkan untuk variabel kekerasan dalam berpacaran dijelaskan dengan salah satu teori pembelajaran sosial Bandura (1977), teori ini memberikan kerangka penjelasan mengenai kekerasan pada pasangan. Ahli teori pembelajaran sosial mengusulkan bahwa sebagian besar perilaku termasuk kekerasan dalam berpacaran, dipelajari melalui respon terhadap perilaku seseorang dan dipaparkan kepada orang lain yang terlibat dalam perilaku tersebut. Para ahli teori sosiologis memeriksa konteks sosial seseorang sebagai sumber pengaruh pada perilakunya, termasuk agresi terhadap pasangan. Teori-teori psikologis menekankan pada perbedaan kepribadian individu dan keluarga sebagai penentu utama untuk menjelaskan mengenai agresi terhadap pasangan, daripada memeriksa konteks sosial-budaya (Schumacher, Feldbau-Kohn, Smith Slep, \& Heyman, 2001). Pada penelitian ini, data kategori variabel kekerasan dalam berpacaran dengan nilai mean sebesar 93,53 dan nilai standart deviasi sebesar 15,107. Kategori tinggi sebanyak $45,4 \%$ yaitu sebanyak 83 subjek, sedangkan pada kategori rendah sebanyak 54,6\% yaitu sebanyak 100 subjek.

Kelebihan dari penelitian ini adalah berfokus pada para pelaku kekerasan dalam hubungan pacaran yang jarang diteliti selama 5 tahun terakhir di Indonesia. Penelitian dalam negeri sebelumnya lebih memilih pada para korban kekerasan dalam berpacaran sehingga dibutuhkan penelitian yang memebahas mengenai para pelaku kekerasan. Terlepas dari bagaimana hasil data dari penelitian ini yang mendukung suatu teori maupun penelitian sebelumnya, penelitian ini juga memiliki beberapa kekurangan yang dapat dikaji pada penelitian selanjutnya. Penelitian ini tidak menjelaskan mengenai pengaruh usia terhadap masing-masing variabel. Hasil dari penelitian ini bersifat spesifik terhadap perilaku mahasiswa tanpa memperhitungkan kategori usia sehingga penelitian hanya sebatas kategori rentang usia saja. 


\section{SIMPULAN DAN IMPLIKASI}

Berdasarkan hasil penelitian dapat disimpulkan bahwa hipotesa diterima yang berarti terdapat hubungan positif yang signifikan pada regulasi emosi dengan kekerasan dalam berpacaran. Artinya semakin tinggi regulasi emosi maka semakin tinggi pula perilaku kekerasan dalam berpacaran, begitupun sebaliknya. Semakin rendah regulasi emosi maka semakin rendah pula perilaku kekerasan dalam berpacaran. Pada uji beda diperoleh hasil bahwa regulasi emosi mahasiswa laki-laki dan perempuan adalah sama. Sedangkan pada hasil kekerasan dalam berpacaran diperoleh hasil bahwa mahasiswa laki-laki dan perempuan adalah tidak ada perbedaan yang signifikan.

Implikasi pada penelitian ini meliputi: Bagi pelaku kekerasan dalam berpacaran agar dapat meregulasi emosi, sehingga tidak menggunakan cara yang maladaptif untuk menyelesaikan suatu konflik dalam hubungan. Bagi peneliti selanjutnya yang tertarik dengan penelitian variabel kekerasan dalam berpacaran dapat meneliti mengenai pengaruh usia dikaitkan dengan variabel terkait. Selain itu dapat meneliti secara spesifik terhadap perilaku mahasiswa dengan memeperhitungkan spesifikasi kategori usia, serta dapat meneliti pengaruh durasi lama pasangan menjalin hubungan. Penelitian ini dapat dilanjutkan dengan mengganti variabel regulasi emosi dengan variabel lain, seperti kepribadian, stress, dan kepuasan hubungan. Perlu dilakukan penelitian dengan metode lain, seperti penelitian eksperimen atau uji banding pada usia, sehingga dapat menghasilkan beragam hasil penelitian yang spesifik terkait kedua variabel.

\section{REFERENSI}

Baird, K. (2015). Understanding the role of emotion regulation in dating violence during adolescence (Vol. 119).

BBC. (2018, April). Lelaki korban kekerasan dalam pacaran: "Berjarak 10 hari dari kematian." $B B C$.

Cooper, M. L. (2002). Alcohol use and risky sexual behavior among college students and youth: Evaluating the evidence*. Journaal of Studies On Alcohol/ Supplement, (14), 101-117.

Gratz, K. L., \& Roemer, L. (2004). Multidimensional Assessment of Emotion Regulation and Dysregulation: Development, Factor Structure, and Initial Validation of the Difficulties in Emotion Regulation Scale. Journal of Psychopathology and Behavioral Assessment, 26(1), 4154. https://doi.org/10.1023/B:JOBA.0000007455.08539.94

Gross, J. J. (2014). Conceptual and empirical foundations. In J. J. Gross (Ed.), Emotion Regulation (Second Edi, pp. 3-20). Guilford.

Komnas Perempuan. (2017). Kekerasan Dalam Pacaran. Komnas Perempuan.

Kuniawan, D. (2018, March). Sudah dianiaya, mahasiswa Surabaya diperkosa pacar 2 kali. Liputan 6, 2.

Lewis, S. F., \& Fremouw, W. (2001). Dating Violence (A critical review of the literature). Clinical Psychology Riview, 21(1), 105-127.

Littaurer, F. (2006). Personality Plus. Jakarta: PT. Rosdakarya.

Luthra, R., \& Gidycz, C. A. (2006). Dating violence among college men and women: Evaluation of a theoretical model. Journal of Interpersonal Violence, 21(6), 717-731. https://doi.org/10.1177/0886260506287312

Mason, B., \& Smithey, M. (2012). The Effects of Academic and Interpersonal Stress on Dating Violence Among College Students: A Test of Classical Strain Theory. 
https://doi.org/10.1177/0886260511423257

NET, I. M. S. (2017). Love line Kekerasan dalam berpacaaran.

Priyono. (2016). Metode Penelitian Kuantitatif. In T. Chandra (Ed.), (edisi 2016, Vol. 91). Sidoarjo: Zifatama Publishing.

Roberton, T., Daffern, M., \& Bucks, R. S. (2012). Emotion regulation and aggression. Aggression and Violent Behavior, 17(1), 72-82. https://doi.org/10.1016/j.avb.2011.09.006

Safitri, W. A. (2013). Dampak Kekerasan Dalam Berpacaran ( The Impact Of Violence In Dating ). Artikel Ilmiah Hasil Penelitian Mahasiswa UNEJ, 1(1), 1-6.

Schumacher, J. A., Feldbau-Kohn, S., Smith Slep, A. M., \& Heyman, R. E. (2001). Risk factors for male-to-female partner physical abuse. In Aggression and Violent Behavior (Vol. 6). https://doi.org/10.1016/S1359-1789(00)00027-6

Shorey, R. C., Brasfield, H., Febres, J., \& Stuart, G. L. (2011). An examination of the association between difficulties with emotion regulation and dating violence perpetration. Journal of Aggression, Maltreatment \& Trauma, 20(January), 870-885. https://doi.org/10.1080/10926771.2011.629342

Shorey, R. C., Cornelius, T. L., \& Bell, K. M. (2008). Behavioral theory and dating violence: A framework for prevention programming. The Journal of Behavior Analysis of Offender and Victim Treatment and Prevention, 1(4), 1-13. https://doi.org/10.1037/h0100452

Shorey, R. C., McNulty, J. K., Moore, T. M., \& Stuart, G. L. (2015). Emotion Regulation Moderates the Association Between Proximal Negative Affect and Intimate Partner Violence Perpetration. Prevention Science, 16(6), 873-880. https://doi.org/10.1007/s11121015-0568-5

Shorey, R. C., Zucosky, H., Bras, H., Febres, J., Cornelius, T. L., Sage, C., \& Stuart, G. L. (2012). Aggression and violent behavior dating violence prevention programming: Directions for future interventions. Aggression and Violent Behavior, 17, 289-296. https://doi.org/10.1016/j.avb.2012.03.001

Sugiyono. (2018). Metode Penelitian Kuantitatif, Kualitatif, dan RED (27th ed.). Bandung: ALFABETA CV.

Tarso. (2017, November). Baru pacaran saja, cewek alumni poltek ini mengalami kekerasan fisik dari cowoknya, ini pengakuannya. SRIPOKU.Com.

Wolitzky-taylor, K. B., \& Ruggiero, K. J. (2008). Prevalence and correlates of dating violence in a national sample of adolescents. J. Am Acad. Child Adolesc, Psychiatry, 47(7), 755-762. https://doi.org/10.1097/CHI.0b013e318172ef5f 